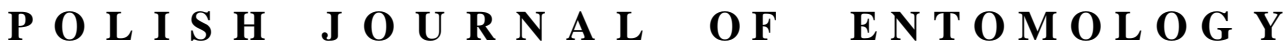

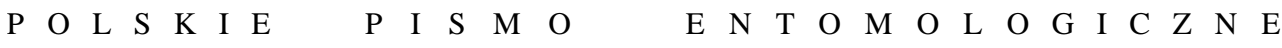

VOL. 83: 225-234

Lublin

30 September 2014

DOI: $10.2478 /$ pjen-2014-0018

\section{Mark-recapture studies on co-occurring Sympecma fusca (VANDER LINDEN, 1820) and S. paedisca (BRAUER, 1877) (Odonata: Zygoptera: Lestidae)}

\author{
THOMAS BROCKHAUS
}

An der Morgensonne 5, D-09387 Jahnsdorf/Erzgebirge, Germany, e-mail: t.brockhaus@t-online.de

\begin{abstract}
Maturation cohorts and reproductive cohorts of the two Sympecma species were studied in Chomutov (Czech Republic) from 2010 to 2013. During individual mark-recapture studies, a total of 705 winter damselflies were recorded, 473 of which were individually marked ( 375 S. fusca, 98 S. paedisca). The recapture rates in the maturation habitat and in the reproductive habitat were low. The population estimate using CHAPMAN's method for low recapture rates could not be carried out separately for the two species owing to the low recapture rate of S. paedisca. The proportion of females was greater in the maturation habitat and significantly lower than that of males in the reproductive habitat. The reproductive habitat was predominantly inhabited by territorial males. All the females observed there were engaged in reproductive activities. There was a close correlation between the male density along the shoreline and reproductive activities. $S$. paedisca was less abundant than $S$. fusca. No differences between the two species were observed in reproductive behaviour. However, S. paedisca appeared to disperse continuously away from the maturation habitat. Perhaps this species prefers more open areas as maturation and wintering habitats. S. fusca was observed here until October.
\end{abstract}

KEY WORDS: Odonata, Sympecma fusca, S. paedisca, mark-recapture study.

\section{INTRODUCTION}

The two winter damselflies Sympecma fusca (VANDER LINDEN, 1820) and S. paedisca (BRAUER, 1877) often live in the same habitat (syntopy) (JÖDICKE 1991, MANGER 2007, HARABIŠ \& JiSKRA 2008, BERNARD et al. 2009, TESKE 2010, MAUERSBERGER et al. 2013). Their use of habitat is also similar, like reproduction habitat, maturation habitat and 
hibernation habitat (JÖDICKE \& MiTAMURA 1995, SCHMIDT \& STERNBERG 1999, STERNBERG \& RADEMACHER 1999, MANGER 2007, TESKE 2010), as is their behaviour (JÖDICKE 1997, SCHMIDT \& STERNBERG 1999, STERNBERG \& RADEMACHER 1999).

Unfortunately, it is difficult to distinguish the two species in the field. Overwintered darkened, adults can only be confidently determined after capture and close examination in the hand.

The following investigation addressed similarities and differences in a habitat harbouring both species and aimed to identify possible differences in population structure and habitat use.

\section{Acknowledgements}

I am grateful to the district administration of the district Ústi nad Labem and to Martin WALDHAUSER for issuing me with a special permit for the investigation of a EU-protected species. Many thanks go to Dr Edyta BUCZYŃSKA and Dr Klaus REINHARDT for their corrections and suggestions while editing this manuscript, and to Bob KEMP who checked the language. I also thank the two anonymous reviewers for their respective comments.

\section{STUDY AREA}

The study area was located in a former gravel or clay pit (approx. 180 ha in area), situated at the edge of Chomutov in the Czech Republic $\left(50^{\circ} 25^{\prime} 30.51^{\prime \prime} \mathrm{N}, 13^{\circ} 25^{\prime} 35.88^{\prime \prime} \mathrm{E}\right)$.

Different sized water bodies are present in the area with large reed beds (Phragmites australis (CAV.) TRIN. ex STEUD.) and submerged vegetation. Other parts of the site are covered with the grass (Calamagrostis epigejos (L.) ROTH), rose bushes, brambles and woody plants at various stages of natural succession.

The observations and mark-recapture experiments were carried out in three different areas.

Section 1 (S1): part of the shoreline of a reproduction habitat with reeds and adjacent terrestrial habitat.

Section 2 (S2): a small reproduction habitat 0.3 ha in area, completely surrounded by a reed belt several metres wide and not shaded by trees. The submerged vegetation consists predominantly of Ceratophyllum demersum $\mathrm{L}$.

Section 3 (S3): This area covers approximately 0.5 ha and is part of the maturation habitat. Aspen and birch trees provide sheltered areas; more open, sunlit areas are present too. Calamagrostis epigejos predominates with small and scattered groups of bushes (wild roses, blackberries, birches). 


\section{METHODS}

During the three surveys, each in the spring of 2010 and 2011, all adults in S1 were recorded. Both species and sex were noted but no individuals were marked.

In the summer of 2011 and 2012, individuals of the maturation cohorts in S3 were marked in a mark-recapture-experiment (permanent marker, consecutive numbers on a wing). Individuals were caught, species and sex were noted, and were then marked and released.

In the spring of 2012, individuals of the reproduction cohort in S2 were also marked. The inner shore line between the reed zone and the water was surveyed using the water trousers.

In 2013, a modified method was used. In S2, a shore length of exactly $300 \mathrm{~m}$ was surveyed. During the first inspection, all available individuals were marked and immediately released. After an interval of one hour, a second inspection was undertaken. Recaptured and unmarked individuals were recorded. Reproductive activities were recorded during both inspections.

In the summer and autumn of 2013, marking in S3 was undertaken for a period of 30 minutes. This was then followed by an interval of one hour before marked and unmarked individuals were again recorded.

The population estimates based on mark-recapture results were carried out in a single estimate for the years 2011 and 2012. In 2013, daily estimates were performed and only the recaptures of the same day used. Owing to the low recapture rate, all population estimates were evaluated according to CHAPMAN's method (POLLOCK et al. 1990). The proportion of species and the proportion of females were determined from the number of captured adults.

\section{RESULTS}

A total of 705 winter damselflies were found (548 S. fusca, 157 S. paedisca) and 473 were individually marked ( 375 S. fusca, 98 S. paedisca). The recapture rates in the maturation habitat were similar across years: $3.5 \%, 4.5 \%$, and $7.2 \%$ in 2011, 2012 and 2013, respectively. In the reproductive habitat, recapture rates were $8 \%$ in 2012 and $4 \%$ in 2013. Because of the low recapture rate of S. paedisca (only 2 recaptures), it was not possible to separate the estimate between the species.

The proportion of S. fusca and S. paedisca in the two populations tended to show an increase in the proportion of $S$. fusca (Tab.). While females mostly predominated in the maturation cohorts, their proportion was significantly lower in the reproductive cohorts (Tab.). 


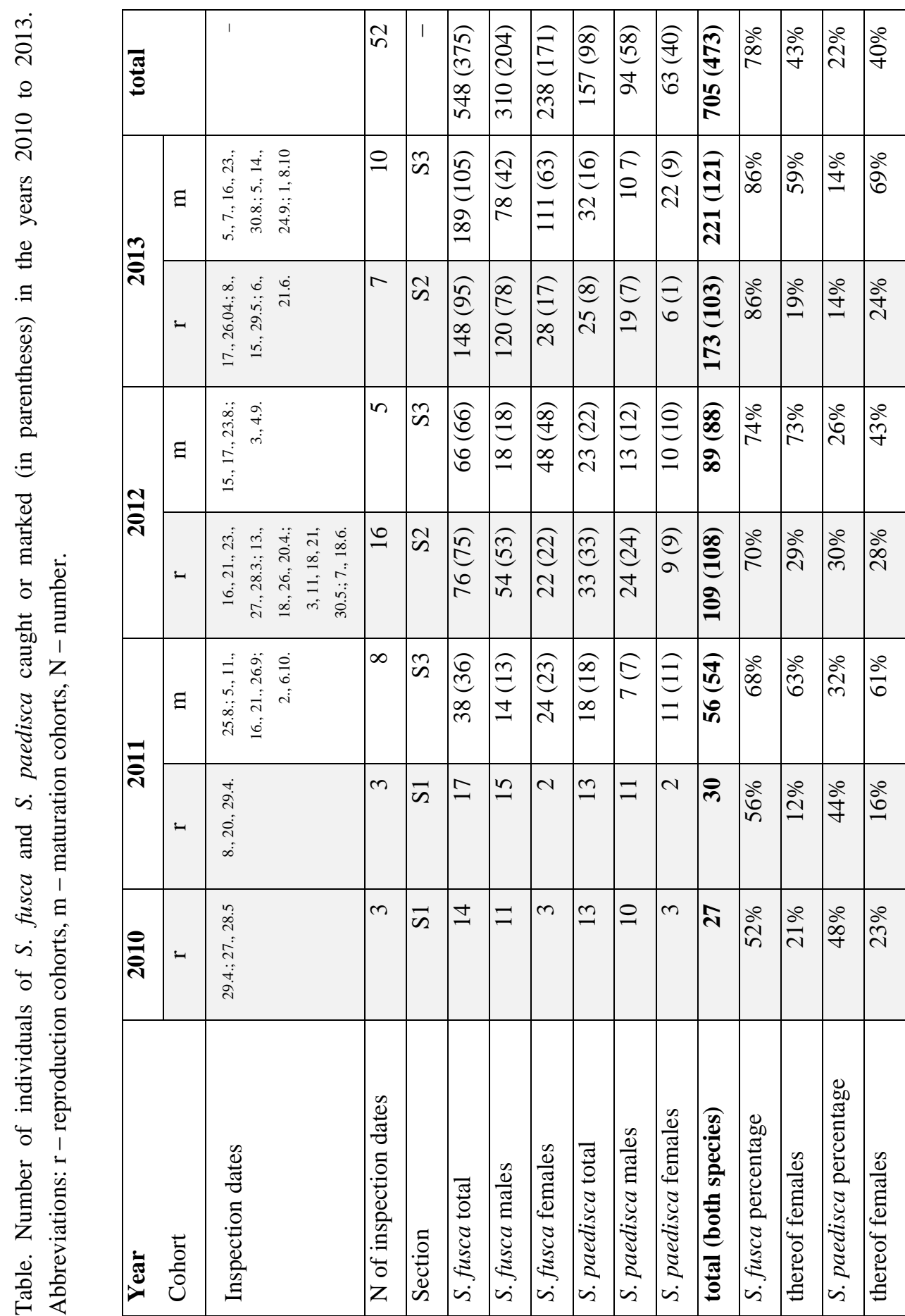




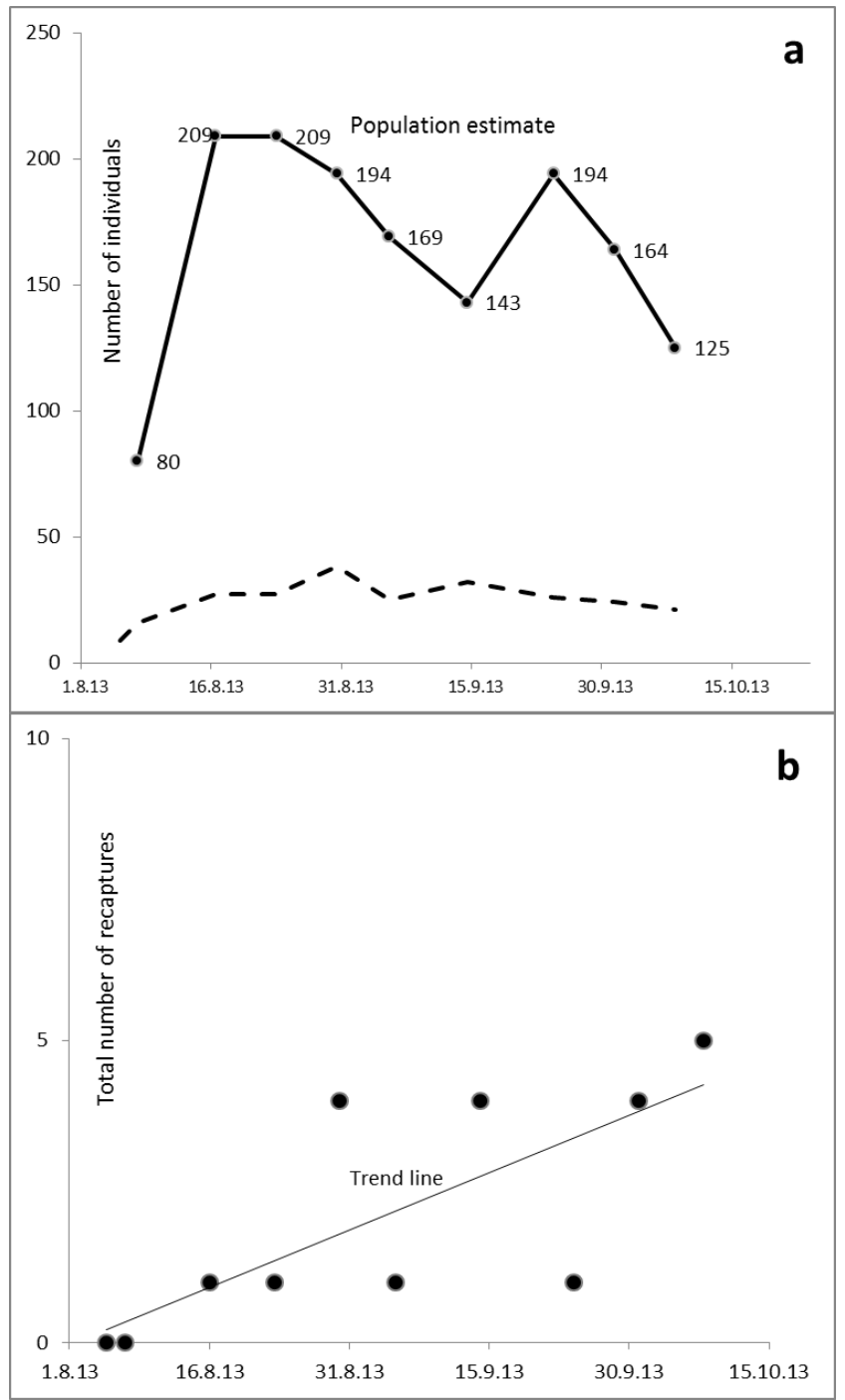

Fig. 1. Population estimate in the maturation habitat (S3) in summer/autumn 2013; a: population estimate (continuous line) and total number (dashed line) of adults caught of the maturation cohort of S. fusca and S. paedisca; b: number of all recaptures on the respective days with trend line.

Population estimates in the maturation habitat (area: 0.5 ha) were 214 in $2011(63 \%$ females), 337 in 2012 (66\% females) and 209 in 2013 (59\% females) (Fig. 1a). In 2013, the total number of recaptures increased from summer to autumn (Fig. 1b). The maturing adults 
of both species were initially found to be exclusively restricted to the Calamagrostis grass stems, but from about September S. fusca would be found basking in the sunshine on the bark and stems of birches, aspen, wild roses and blackberries. The latest observation of an adult (S. fusca) took place on 8 October 2013.

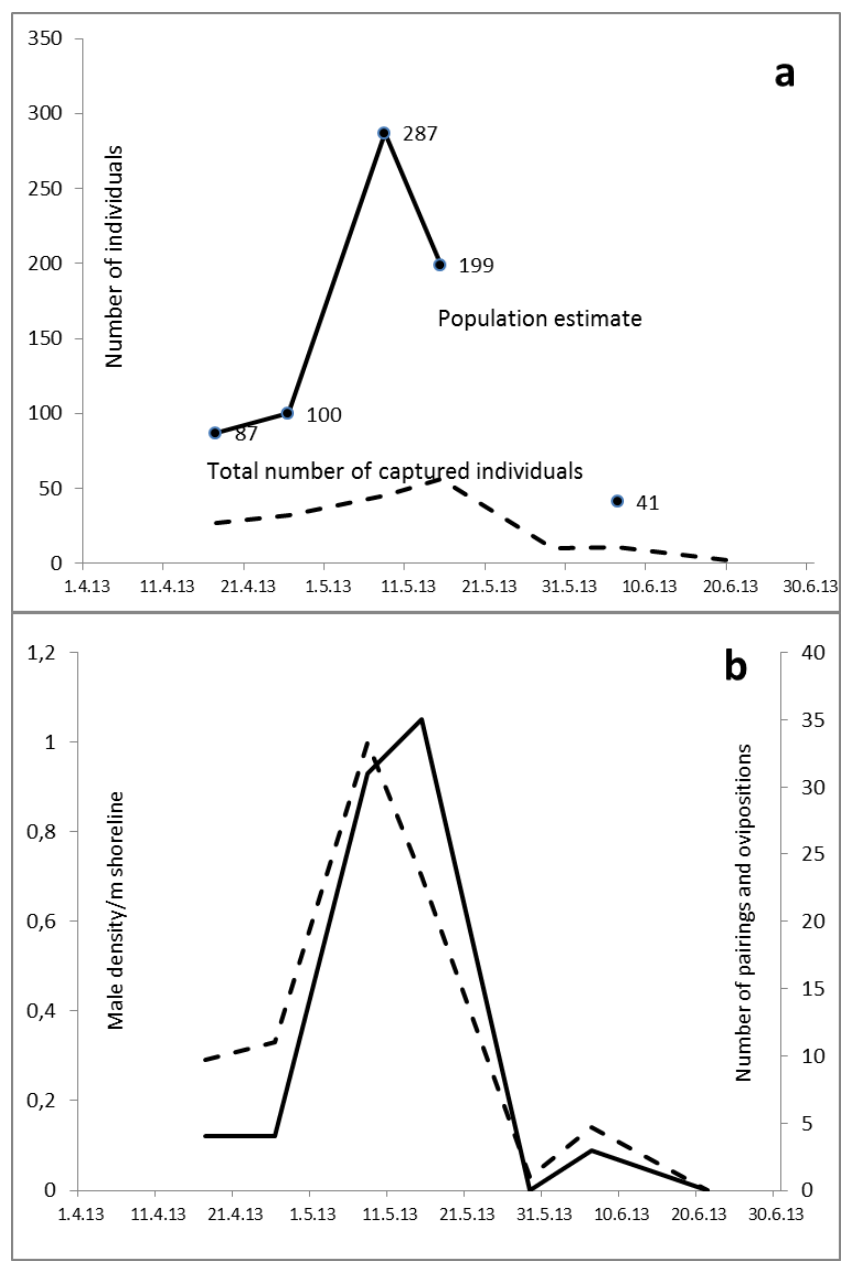

Fig. 2. Population estimate in the reproductive habitat (S2) in spring 2013; a: population estimate and total number of adults caught of the reproduction cohort of S. fusca and S. paedisca (no recaptures on 29 May); b: male density (dashed line) and reproductive activities (continuous line). 
The earliest reproductive activity observed over the survey period was in S1 on 23 March 2012. On this day, a mispairing between a male of S. paedisca and a female of S. fusca was also observed. S2 was predominantly populated by males. They mainly occupied horizontal reed stems about $0.5 \mathrm{~m}$ above the water surface. All the females observed here were engaged in reproductive activities (tandem pairs, copulating pairs, oviposition, usually in tandem). The population estimate on the $300 \mathrm{~m}$ shore length, in spring 2012, revealed 181 individuals (29\% females), 287 at maximum in spring 2013 (Fig. 2a) (max. $26 \%$ females). There was a close correlation between the male density along the shoreline and female reproductive activities (Fig. 2b). The adults, single or in tandem, were readily disturbed and would fly off into the adjacent reed bed. Males were very aggressive towards other males. Males flying by were attacked from a distance of $50 \mathrm{~cm}$. From May onwards, males would also display a similar behaviour towards individuals of Enallagma cyathigerum and Coenagrion puella. In turn, Sympecma males were attacked by Erythromma najas, whose mature males had immigrated to the water, and also by Cordulia aenea.

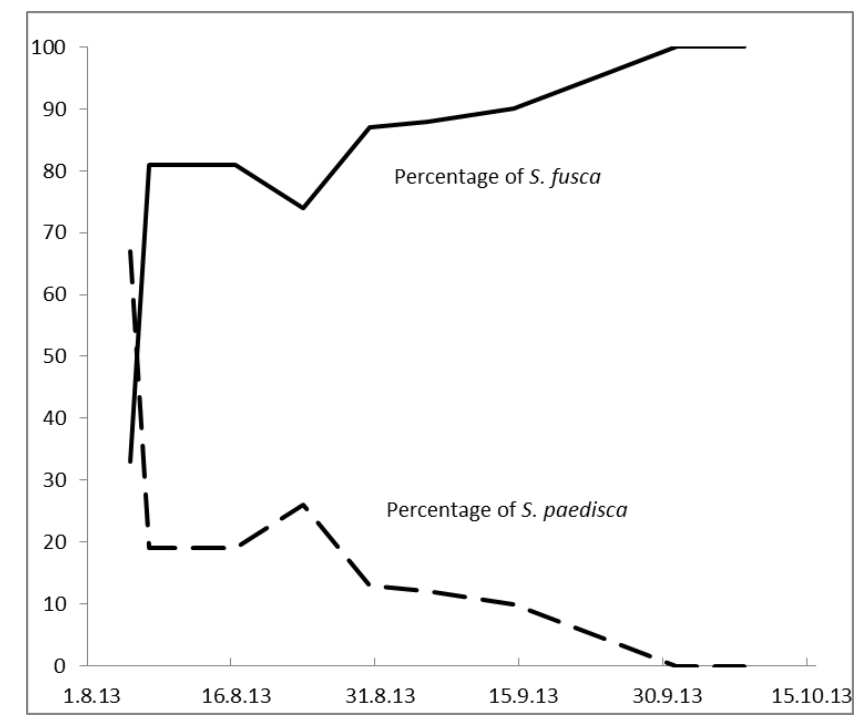

Fig. 3. Proportion of the two species of Sympecma in the maturation habitat (S3) in 2013.

The proportion of S. paedisca of all Sympecma individuals was usually smaller than that of $S$. fusca (Tab.). Only in S1, in the region of the large reproductive habitat, was the proportion of S. paedisca (48\% in 2010 and $44 \%$ in 2011) higher than that in the 
reproductive habitat S2 (30\% in 2012, 14\% in 2013) and in the maturation habitat S3 (32\% in 2011, 26\% in 2012 and $14 \%$ in 2013). In summer/autumn 2013, the proportion of individuals of S. paedisca decreased continuously in the maturation habitat (Fig. 3).

Some individuals of $S$. fusca were observed over several weeks. A female was marked on 23 August 2013, and was subsequently recaptured on two occasions, for the second time on 8 October 2013. This was the latest observation of an adult. The hibernation sites of the two species were not found.

\section{DISCUSSION}

Three distinct life stages can be distinguished in adults of winter damselflies: the emergence and maturation phase, hibernation and the reproductive phase (JÖDICKE 1997). In the study area, the maturation habitat was located immediately adjacent to the reproductive habitat. At the beginning of the emergence, all individuals were found in Calamagrostis stands. Possibly, the adults take up a larger terrestrial habitat for maturation (JÖDICKE 1991, SCHMIDT \& STERNBERG 1999). The estimated population density was a maximum of only 0.7 individuals $/ \mathrm{m}$ in S3 (summer 2012). Nearly always, the adults were one or more metres apart, probably requiring a certain area as foraging habitat. Individuals were observed here making short flights (distances of up to $50 \mathrm{~cm}$ ) from their perch towards very small prey (Diptera?). Some S. fusca individuals remained in the maturation habitat for several weeks (see also SCHWEIGHOFER 2011). From about mid-September, S. fusca changed their location from the grass stems to sunny exposed areas (tree trunks, shrubbery). Aggregations of several adults were also observed but individuals were still at least $50 \mathrm{~cm}$ apart. By contrast, $S$. paedisca left the maturation habitat relatively soon (see also SCHMIDT 1993). How they were distributed over the total area remains unknown. Perhaps they prefer more open areas for maturation and wintering habitats (KETELAAR et al. 2007, TESKE 2011), such as S3. The maturation habitats of S. fusca are characterized by scattered groups of trees (e.g. SCHWEIGHOFER 2011, this study). SCHMIDT \& STERNBERG (1999) described the typical features of a steppe as triggering signals for the presence of S. paedisca. JÖDICKE \& MITAMURA (1995) suspected that there might be species-specific preferences for hibernation sites. In this study, however, we were unfortunately unable to confirm this as no wintering areas were found.

The greater proportion of $S$. paedisca in S1 compared to other areas may be an indication that this species prefers larger water bodies for reproduction. The reproductive intensity of both species was regulated by the male density on reproductive habitat. Females may also exert some control over reproductive activities by their presence or absence over the water. Reproductive activity early in the year, with a maximum in the 
middle of May (Fig. 2b), probably gives the two species a competitive advantage over other species of Odonata that reproduce here (HARABIŠ et al. 2012). Aggressive behaviour of males towards egg-laying females or couples (WÜNSCH et al. 2013) was observed only infrequently.

\section{REFERENCES}

Bernard R., Buczyński P., Grzegorz T., Wendzonka J. 2009. A distribution atlas of dragonflies (Odonata) in Poland. Bogucki Wydawnictwo Naukowe, Poznań.

HARABIŠ F., JISKRA P. 2008. The occurrence of Sympecma paedisca (Odonata) in the Czech Republic. [in:] A. DolnÝ (ed.). Vážky 2008. Sborník referátů XI. celostátního semináře odonatologů v Českém lese. ZO ČESOP Vlašim, Vlašim, 141-144. (in Czech)

HARABIŠ F., DOLNÝ A., ŠIPOŠ J. 2012. Enigmatic adult overwintering in damselflies: coexistence as weaker intraguild competitors due to niche separation in time. Population Ecology 54(4): $549-556$.

JÖDICKE R. 1991. Herbstphänologie mitteleuropäischer Odonaten. 1. Beobachtungen in Oberbayern, Bundesrepublik Deutschland. Opuscula zoologica fluminensia 62: 1-11.

JöDiCKE R. 1997. Die Binsenjungfern und Winterlibellen Europas. Die Neue Brehm-Bücherei Bd. 631. Westarp-Wissenschaften, Magdeburg.

JÖDICKE R. \& MiTAMURA T. 1995. Contribution towards an annotated bibliography on hibernation in Sympecma BURMEISTER (Odonata: Lestidae). Opuscula zoologica fluminensia 133: 1-9.

Ketelaar R., Ruiter E.J., Uihoorn H.M.G., Manger R., De Boer E.P. 2007. Habitat choice of Sympecma paedisca in the Netherlands. Brachytron 11(1): 21-33. (in Dutch)

MANGER R. 2007. Both Sympecma paedisca and Sympecma fusca in the same breeding habitat. Brachytron 11(1): 83-86. (in Dutch)

Mauersberger R., Brauner O., Petzold F., Kruse M. (eds) 2013. Die Libellenfauna des Landes Brandenburg. Naturschutz und Landschaftspflege in Brandenburg 22(3/4): 1-166.

Pollock, K.H., Nichols J.D., BRownie C., Hines J.E. 1990. Statistical interference for capturerecapture-experiments. Wildlife Monographs 107: 1-97.

SCHмiDT B. 1993. Die Sibirische Winterlibelle (Odonata) im südwestlichen Alpenvorland. Carolinea 51: 83-92.

SCHMIDT B., STERNBERG K. 1999. Sympecma paedisca (BRAUER, 1877). Sibirische Winterlibelle. [in:] STERnBERG K., BuchwAld R. (eds). Die Libellen Baden-Württembergs. Band 1. Ulmer. Stuttgart, 440-451.

SCHWEIGHOFER W. 2011. Ein Jahr mit Sympecma fusca in Niederösterreich (Odonata: Lestidae). Libellula 30(3/4): 157-172.

STERnBERG K., RADEMACHER M. 1999. Sympecma fusca (VANDER Linden, 1820). Gemeine Winterlibelle. [in:] SteRnBerg K., Buchwald R. (eds). Die Libellen Baden-Württembergs. Band 1. Ulmer. Stuttgart:429-440. 
Teske A. 2011. Herbstlebensräume von Sympecma paedisca (BRAUER 1877) und S. fusca (VANDER LiNDEN, 1820) im Bereich Thülsfelder Talsperre (LK Cloppenburg). Drosera 2010: 149-158.

WÜNSCH H.-W., GospodinOva H., HEYdRICH W. 2013. Beobachtungen zum Fortpflanzungsverhalten von Sympecma fusca (Odonata: Lestidae). Libellula 32(3/4): 187-192.

Received: 17 February 2014

Accepted: 1 July 2014 